\title{
Foam-cell Reticulosis of Mice: An Inherited Condition Resembling Gaucher's and Niemann-Pick Diseases
}

\author{
MARY F. LYON, E. V. HULSE, and C. E. ROWE*
}

\begin{abstract}
From the Medical Research Council Radiobiological Research Unit, Harwell, Didcot, Berkshire, and the National Institute for Medical Research, Mill Hill, London N.W.7
\end{abstract}

An inherited disease, which histologically resembles the lipid-storage diseases in man, has arisen spontaneously in the CBA mice of the Radiobiological Research Unit. The affected animals cannot be recognized until they are at least 3 months old, and do not live long after the disease has developed. It is difficult to maintain a breeding stock and consequently genetic studies have been limited. The chemical aspects have also proved difficult to elucidate, but, as the disease is unusual and bears a resemblance to a poorly understood group of human diseases, it has been thought worth while to put on record the results which have been obtained.

\section{Description of the Disease}

Affected animals became noticeably thin when ro-14 weeks old. The abdomen lost its normally slightly rounded contour, and loose folds of skin appeared on the flanks. The animals continued to lose weight, became hunched, and their activity decreased. Respiratory movements became unduly obvious and many of the mice made a clicking sound during respiration. Death occurred within a few weeks and none of the animals lived to 6 months.

Post-mortem Appearances (Fig. I). In all the affected animals the thymus and Peyer's patches were abnormal. The thymus was uniformly enlarged, and instead of its normal greyish, semitranslucent appearance it was opaque and white. The Peyer's patches were very enlarged and were obviously infiltrated with the same opaque, white material as the thymus. Most of the increase in size was immediately beneath the peritoneum and there was no evidence of the intestinal lumen being encroached upon. In a few instances the

Received December 3, 1964.

* Present address: Department of Physiological Chemistry, University of Birmingham. whole of the wall of the terminal ileum was infiltrated with the same material. There was no generalized enlargement of the lymph nodes but the mediastinal lymph nodes were infiltrated in about half the affected animals and the mesenteric lymph node was infiltrated in about one-quarter.

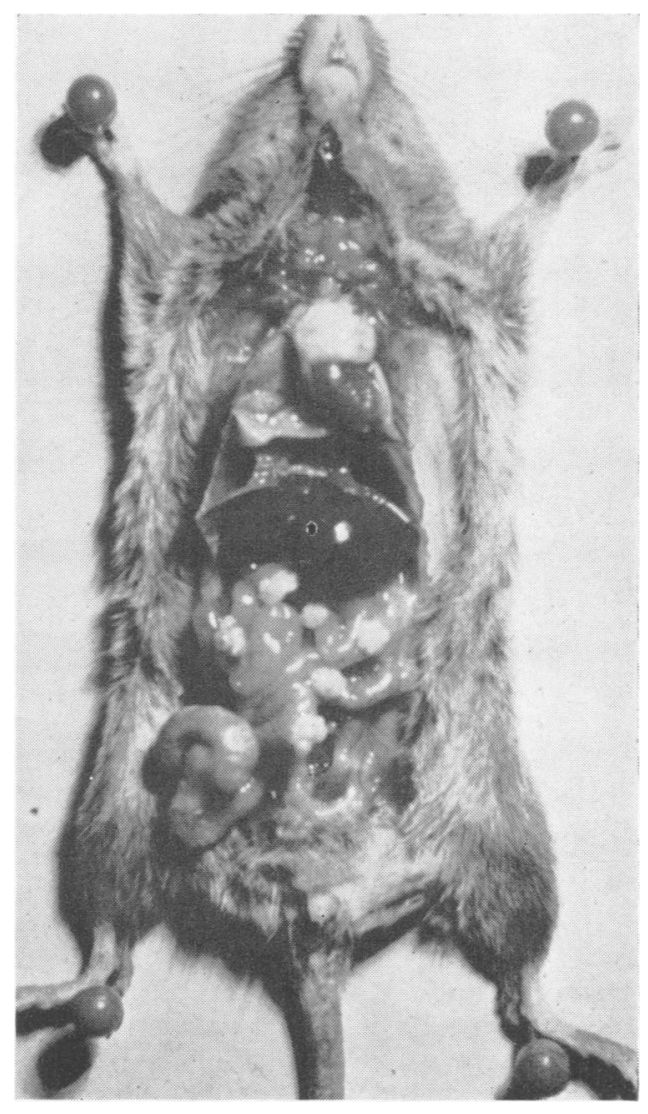

Frg. I. Post-mortem appearances of an affected mouse, showing enlargement of thymus and Peyer's patches. 


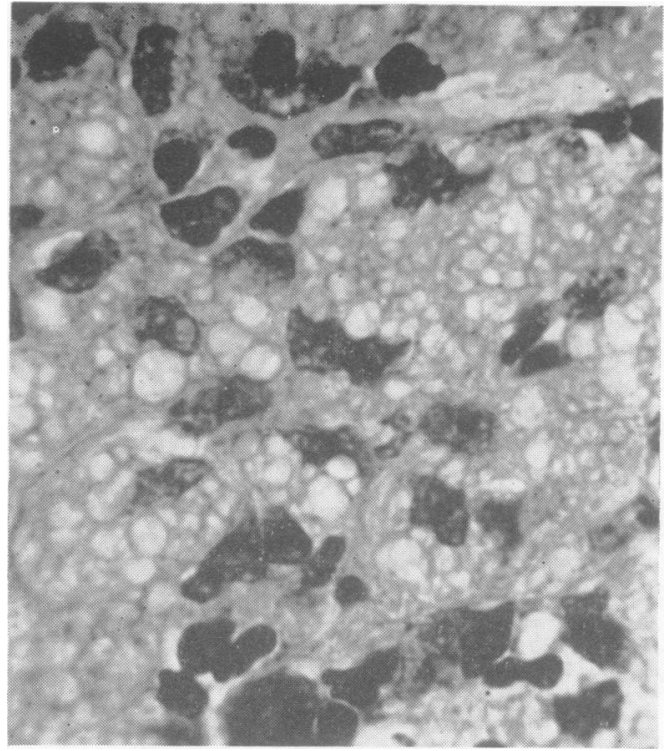

Fig. 2. Foam-cells in the thymus of an affected mouse. (H. and E. $\times$ 900.)

Occasionally the superficial cervical nodes were involved but no other groups of lymph nodes were affected on naked-eye examination. The loose connective tissue of the mediastinum and of the abdomen was fairly frequently affected. Occasionally deposits were found on the peritoneal surfaces of the spleen and liver, but neither organ was enlarged. The uterus was occasionally infiltrated and deposits in the muscles of the scapula were sometimes seen. Only very occasionally was there naked-eye evidence of deposits in the lungs, but lung abscesses were a common complication leading to the death of the animal.

\section{Histology}

THYMUS. In advanced cases normal thymic tissue was replaced by characteristic foam-cells measuring 15 to $40 \mu$ across. Their cytoplasm stained pink with haematoxylin and eosin and usually contained numerous vacuoles of varying size in formalin-fixed, paraffin-embedded material (Fig. 2). Sometimes the vacuoles were very small and occasionally the vacuolated appearance was replaced by a mass of fine striae giving a generalized fibrillary appearance to the cell. The majority of cells contained a single, irregularly oval, leptochromatic nucleus but some bi-nucleate cells were also present. Small deposits of calcium were found scattered amongst these cells, particularly near the centre of the gland. If any lymphoid tissue remained

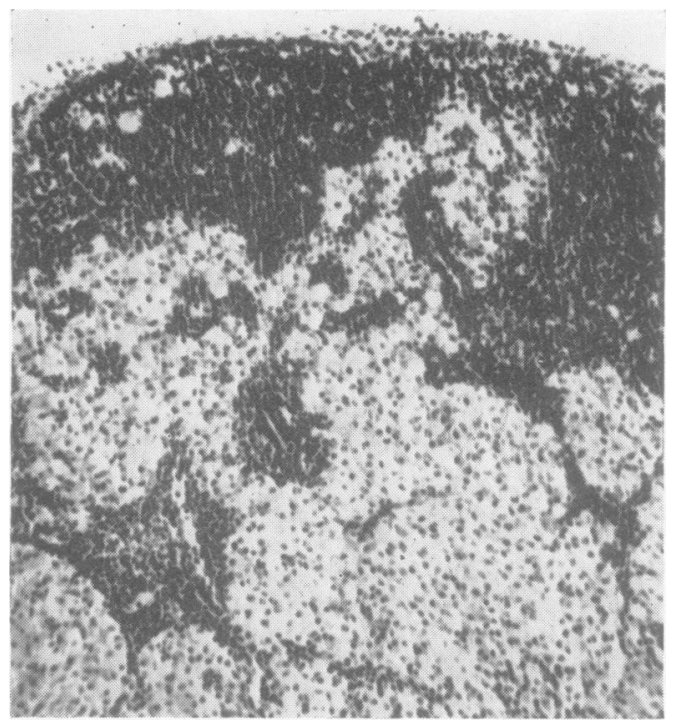

FIg. 3. Thymus from a mouse with foam-cell reticulosis. The $\overparen{D}$ thymus is not completely replaced by diseased tissue and some $\rightarrow$ lymphoid tissue is still present at the periphery. (H. and E. $\times$ 108.) $\overrightarrow{0}$

it was usually confined to the periphery of the lobule (Fig. 3).

PEYeR's Patches. In the early stages foam-cells similar to those seen in the thymus were concentrated $\stackrel{\mathbb{Q}}{\Omega}$ in a narrow zone immediately beneath the muscle $\overrightarrow{\vec{\sigma}}$ layers and frequently the adjacent lymphocytes $\frac{3}{3}$ were degenerating (Fig. 4). In the fully developed $כ$ lesion the lymphoid tissue was completely replaced by foam-cells and sometimes these cells penetrated the muscle layer and came to lie immediately beneath the visceral peritoneum. They were not $\overline{-}$ seen to penetrate the mucosa and no calcium deposits were found.

LYMPH NODES. Microscopically the mediastinal lymph nodes were invariably infiltrated with foamcells. Similar infiltrations were frequently seen in $\frac{D}{0}$ the mesenteric and superficial cervical nodes but lymph nodes in other sites were only very rarely $N$ affected. The infiltration of the lymph nodes was $N$ rarely as complete as that of the thymus or Peyer's N patches and foci of lymphocytes were usually ${ }_{0}^{\omega}$ present in affected nodes.

OTHER VISCERA. In addition to the occasional $\frac{}{\Phi}$ surface deposits, histological examination of the ${ }^{\text {? }}$ spleen and liver regularly revealed small scattered foci of two or three foam-cells. Large infiltrations $\frac{O}{\mathbb{D}}$ in the lungs were rare but small perivascular lesions were a very consistent finding. Apart from $\stackrel{\curvearrowright}{\stackrel{\otimes}{\Omega}}$ 


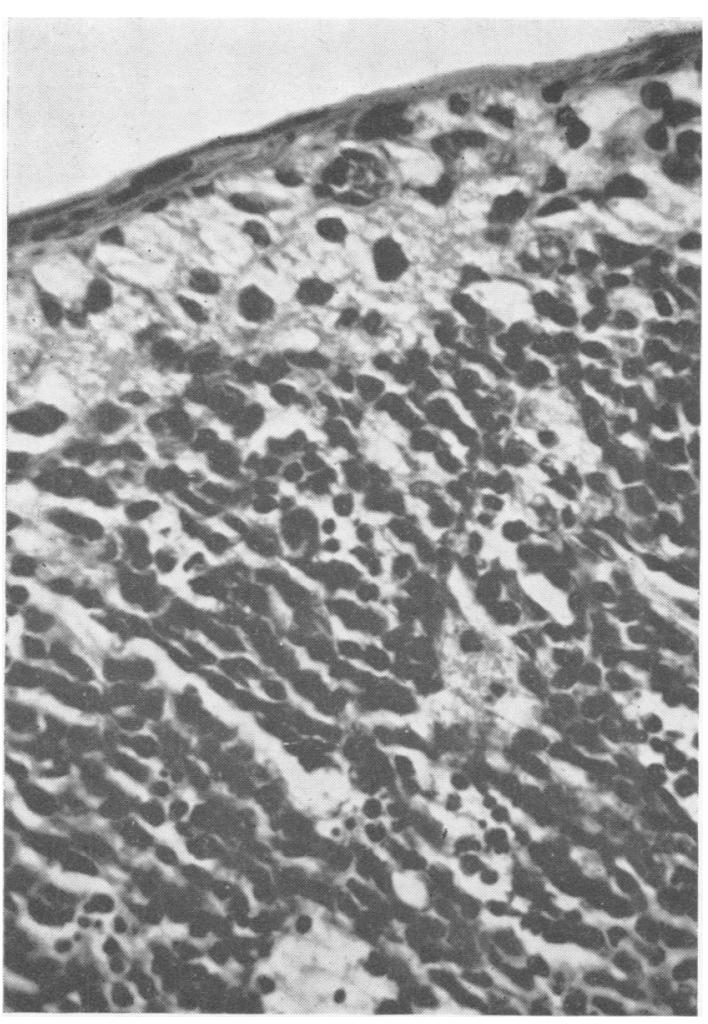

FIG. 4. Early lesion on a Peyer's patch showing degenerating lymphocytes in the lymphoid tissue and foam-cells at the periphery. $(\mathrm{H}$. and E. $\times 475$.

the animals in which lung abscesses were found a purulent bronchitis was noted in a few cases. The deposits in the uterus and in muscle consisted of a mass of foam-cells. No foam-cells were found in the kidneys or the brain and no lesions were found in bone or bone-marrow.

\section{Investigations}

None of the evidence suggested that the disease was infectious or neoplastic. Attempts were made to transmit it to normal healthy CBA mice by means of intraperitoneal or intramuscular injections of saline suspensions of affected thymus. The injected animals were watched for nine months during which time they remained healthy. Postmortem examination failed to reveal any evidence of the foam-cell reticulosis.

Histochemical Investigations. The foamy appearance of the characteristic cells of the disease suggested that some material had been dissolved out of them during histological preparation.
When formalin-fixed material was stained with Sudan Black or Oil Red O the affected cells were only weakly stained, but after fixation in formolcalcium and post-chromation they were strongly positive with both stains. The affected tissues, usually thymus and Peyer's patches, were, therefore, subjected to further stains for lipids. Unless otherwise stated, those methods recommended by Pearse (1960) were used.

Baker's acid haematein method for phospholipids was positive, the dark-blue staining material appearing as fine granules in the affected cells. The degree of staining varied, some cells were packed with positive granules but in others of similar size and appearance they were much less numerous. After Baker's pyridine extraction the cells were uniformly negative and had the foamy appearance of cells that had been paraffin embedded. Okamoto's mercury diphenylcarbazone method, Menschik's Nile blue method for phospholipids, the copper phthalocyanin method, and Rawitz inversion staining (Przetęcka, 1959) were also used and showed a phospholipid distribution similar to that seen with Baker's acid haematein.

Cholesterol and its esters were tested for using Schultz's method with and without digitonin treatment, Okamoto's method, the bismuth trichloride method, and Adams' (I96I) method, all of which gave negative results.

The plasmal reaction, using both Cain's and Hayes' methods, was positive. Nile blue staining for neutral and acidic lipids was weakly positive and Feyrter's method for acidic lipids was negative. The long Ziehl-Neelsen for acid-fast lipofuscins, Fischler's method for fatty acids, and the performic acid-Schiff method, and U-V Schiff method for lipids containing unsaturated bonds were all negative. No silvery white secondary fluorescence was obtained after Phosphine $3 \mathrm{R}$ staining. Staining for soaps with haematoxylin (Gurr, 1958) was also negative.

Chemical Investigations. In view of the histological similarities with the human lipid storage diseases, lipid was extracted from the thymus glands of both diseased and normal CBA mice. The extract was analysed for cholesterol and phospholipid classes. Serum cholesterol was also estimated. All analyses were performed in duplicate.

Extraction OF LipID. Pieces of mouse thymus of approximately I c.mm. were allowed to stand in ethanol-ether ( $2: 1$ by volume: $100 \mathrm{ml}$.) overnight. The solvent was decanted and the residue extracted with $30 \mathrm{ml}$. boiling ethanol-ether for 3 minutes. 
The residue was recovered by centrifugation and extracted with $30 \mathrm{ml}$. boiling chloroform methanol (2:r by volume) for 3 minutes. All extracts were combined and concentrated to dryness using a rotary evaporator. The residue was extracted three times with I ml. of acetone and three times with I ml. ethanol. The ethanol extract was centrifuged to remove insoluble matter. The acetone and ethanol extracts were combined and diluted to Io $\mathrm{ml}$. with ethanol.

ANALYSIS OF PHOSPHOLIPIDS. Extracts containing $0.3 \mu$ mole of phosphorus were chromatographed on silica-impregnated paper using the solvents diisobutyl-ketone-acetic acid-water as described by Marinetti and Stotz (1956). After development of the chromatograms with Rhodamine 6G the separated phospholipid classes were cut out and eluted from the paper with chloroform methanol $2: 1$, and estimated for phosphorus. The procedure was that of Berenblum and Chain (1938) except that (i) ashing was achieved with $5 \mathrm{ml}$. of a mixture of $60 \%$ perchloric acid and sulphuric acid (I:I.5 by volume); (ii) $5 \mathrm{ml}$. of isobutyl alcohol was used for extraction; and (iii) $0.10 \mathrm{ml}$. stannous chloride solution $(40 \% \mathrm{w} / \mathrm{v}$ in concentrated hydrochloric acid) was added to the extract in isobutyl alcohol after washing. For each phospholipid class a piece of blank chromatogram identical in area and distance from the origin was cut out and extracted in an identical manner to give a blank phosphorus estimation.

The components were identified (i) by their positions on the chromatogram relative to each other, and to both egg lecithin and commercial sphingomyelin (California Biochemicals Corpn); and (ii) by their fluorescence in ultraviolet radiation after treatment of the chromatogram with Rhodamine 6G. Phosphatidyl ethanolamine and phosphatidyl serine were detected by their purple colour when the chromatogram was sprayed with ninhydrin and heated at $110^{\circ} \mathrm{C}$. for 10 minutes. Choline-containing phospholipids, e.g. lecithin and sphingomyelin, were detected by treatment of the chromatogram with phosphomolybdic acid followed by reduction (Chargaff, Levine, and Green, 1948).

Cholesterol was measured by the method of Bloor (I9I6).

Results. The total phospholipids in the thymus tissue from diseased and normal mice were the same (Table I). There was, however, a difference in the distribution of phospholipid classes. The diseased tissue contained an additional component not found in normal thymus. This component, though not conclusively identified, had the chrom-
TABLE I

CHOLESTEROL AND PHOSPHOLIPID CONTENT OF POOLED THYMUS GLANDS AND CHOLESTEROL CONTENT OF POOLED SERUM FROM DISEASED AND NORMAL MICE OF SAME AGE

\begin{tabular}{l|c|c}
\hline & $\begin{array}{c}\text { Diseased } \\
\text { Mice }\end{array}$ & $\begin{array}{c}\text { Normal } \\
\text { Mice }\end{array}$ \\
\hline $\begin{array}{c}\text { Total cholesterol (free plus esterified) } \\
(\mu \text { moles/g. wet tissue) }\end{array}$ & 34 & $9 \cdot 8$ \\
$\begin{array}{c}\text { Serum cholesterol (free plus esterified) } \\
(\text { mg./ml.) }\end{array}$ & I.5 & I.4 \\
$\begin{array}{c}\text { Thymus phospholipid } \\
(\mu \text { moles phosphorus/g. wet tissue) }\end{array}$ & I I & I0 \\
\hline
\end{tabular}

atographic and staining properties of lysolecithin (Table II).

The diseased tissue had an abnormally high i content of cholesterol (free plus esterified) (Table I). i The level of serum cholesterol in the serum of $\mathscr{C}$ diseased mice has the same as that in the serum of $\frac{}{9}$ normal mice.

Genetics. The circumstances in which the $\frac{\complement}{\overline{1}}$ original affected animals were found, among the $\vec{\theta}$ progeny of two pairs with common ancestors $2-3$ o generations back, suggested that the disease might be due to an autosomal recessive gene. Since the character did not become obvious until the mice were 3-4 months old, and since the affected animals died shortly thereafter, it was not possible $\stackrel{2}{\circ}$ to plan a genetic programme. Animals had to be $\mathbb{Q}$ paired before it was known whether they were $\overrightarrow{\overrightarrow{0}}$ normal or affected, and the affected ones left very 3 few progeny.

In view of these difficulties, the possible ways? of testing the hypothesis of an autosomal recessive genetic basis were as follows:

(I) To observe the proportions of affected young $\overline{0}$ in the offspring of the various types of matings. among normal and affected parents.

(2) To note what proportion of normal young bred as though heterozygous for the postulated응 gene and what proportion as homozygous normal. $\rightarrow$

All the matings were made within the subline? of $\mathrm{CBA} / \mathrm{H}$ in which the mutation occurred, with

\section{TABLE II}

PHOSPHOLIPID COMPONENTS AS \% OF TOTAL LIPIDCW IN THYMUS GLANDS FROM DISEASED AND NORMALO MICE OF SAME AGE

\begin{tabular}{l|c|c|}
\hline & Diseased Mice & Normal Mice \\
\hline Lysolecithin & 36.2 & 0 \\
Sphingomyelin & $9 \cdot 0$ & 7.3 \\
Lecithin & $37 \cdot 1$ & 68.9 \\
Phosphatidyl serine & $\begin{aligned} 1 \\
\text { Phosphatidyl ethanolamine }\end{aligned}$ & 6.5
\end{tabular}


TABLE III

SEGREGATION OF ANIMALS AFFECTED WITH FOAM-CELL' RETICULOSIS $(\mathrm{fm})$ AMONG PROGENY OF PAIRS OF VARIOUS TYPES

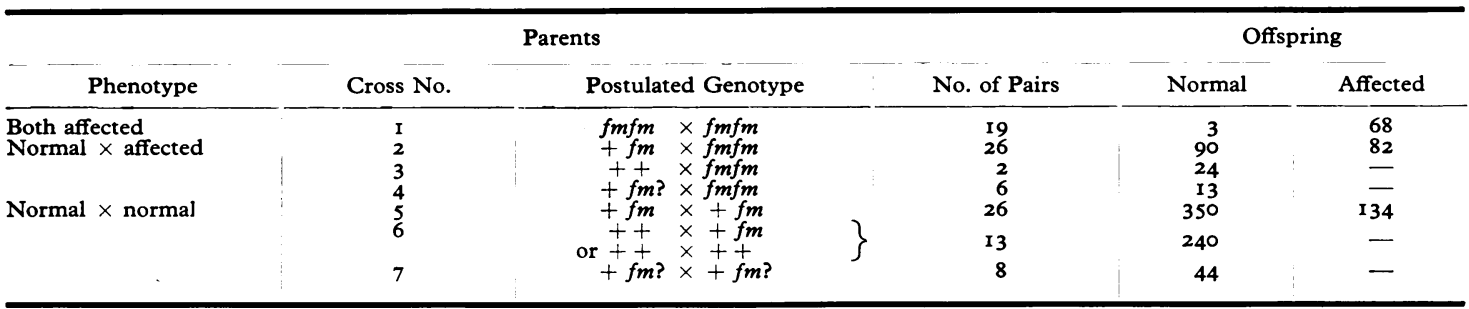

no outcrosses to other stocks, and in most, but not all, cases the mated animals were sibs. The name foam-cell reticulosis, symbol $\mathrm{fm}$, is used to denote the postulated recessive gene concerned.

The possible types of pairs were: normal $\times$ normal, normal $\times$ affected, and affected $\times$ affected. If the disease were indeed due to a recessive gene some of the normal animals would be expected to be homozygous for the wild-type allele, and in line with this some matings of normals threw no affected young. In Table III the results from these crosses (Nos. 3 and 6) are shown separately from those that did give affected offspring. In addition, there were other crosses (Nos. 4 and 7) which produced very small numbers of young (less than 7 young per mating in cross 4, and less than II in cross 7), so that it was not certain whether the unaffected parent was heterozygous or homozygous normal. The Table shows that the results from the segregating matings (crosses 2 and 5) were in good agreement with the expected $I: I$ and $3: 1$ ratios. For cross $2 \chi^{2}$ was 0.37 for $I$ degree of freedom ( $p>$ $0.50)$ and for cross 5 it was $I .86(p>0.10)$. The data will have been slightly biased in favour of affected animals by the exclusion of the pairs in crosses 4 and 7 , since in some at least of these pairs the normal parent will have been a heterozygote which by chance produced no affected offspring. Even if all the progeny of crosses 4 and 7 are included with those of 2 and 5, however, the figures would still show no significant deviation from the expected ratios. The single unexpected fact in the data of Table III is the occurrence of 3 normal animals among the offspring of matings of two affected parents (cross 1 ). Thus on the whole these data support the hypothesis of a single recessive gene, but are not adequate to establish it.

Further support was obtained from tests of the genotypes of the normal offspring. Normals from normal $\times$ affected matings should all be heterozygotes and throw affected offspring, whereas some normals from normal $\times$ normal matings should be homozygous wild-type. Forty-six normal offspring of normal $\times$ affected parents produced enough young to establish their genotype, and all proved themselves heterozygous (Table IV). On the other hand, of the normals from presumed $+f m \times+f m$ matings, 2 out of Io gave no affected progeny when paired with affected mates, and 14 out of 25 behaved similarly when paired with normal mates. In this latter case, one of the normal animals of the pair could have been heterozygous, and therefore these I4 animals are shown in Table IV as of the genotype $+f m$ ?

The data of Table III were further analysed to test for sex-linkage of the gene concerned. The figures from those matings which gave information on this point are shown in Table V; $\chi^{2}$ for deviation from independent segregation (calculated by Fisher's scoring method (Green, 1963)) was $2 \cdot 25$

TABLE IV

THE GENOTYPE, ESTABLISHED BY BREEDING, OF NORMAL OFFSPRING FROM PAIRS OF VARIOUS TYPES

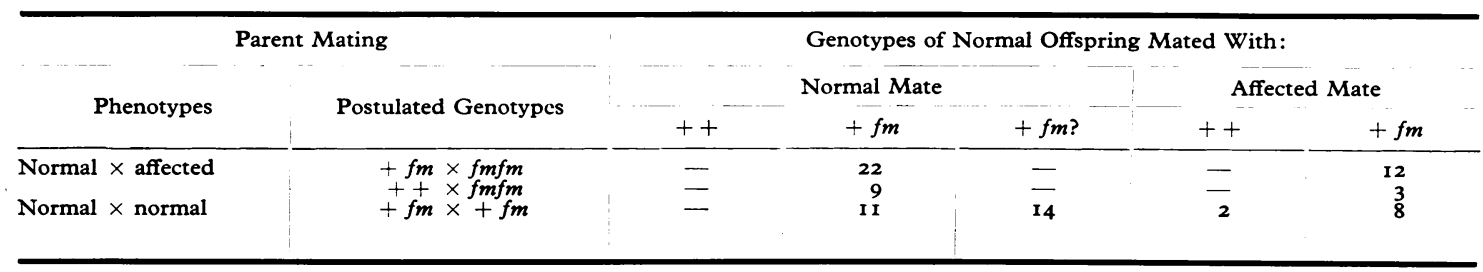


TABLE V

TEST FOR SEX-LINKAGE OF THE POSTULATED RECESSIVE GENE CONCERNED IN FOAM-CELL RETICULOSIS

\begin{tabular}{|c|c|c|c|c|c|c|}
\hline \multirow{2}{*}{ Parents } & \multicolumn{4}{|c|}{ Phenotypes of Offspring } & \multirow{2}{*}{ Score } & \multirow{2}{*}{$I^{*}$} \\
\hline & $+q$ & $f m$ \% & $+\delta$ & $f m$ o & & \\
\hline 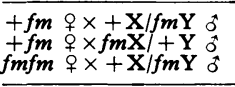 & $\begin{array}{r}88 \\
9 \\
1\end{array}$ & $\begin{array}{r}42 \\
1 \\
3 \\
\end{array}$ & $\begin{array}{r}98 \\
3 \\
4\end{array}$ & $\begin{array}{r}3 \mathbf{3} \\
\mathbf{2} \\
\mathbf{2}\end{array}$ & $\begin{array}{r}+28 \cdot 6 \\
+\quad 6.0 \\
+\quad 8.0 \\
\end{array}$ & $\begin{array}{r}345 \cdot 3 \\
20 \cdot 0 \\
40 \cdot 0 \\
\end{array}$ \\
\hline & & & & Total & +30.6 & $415 \cdot 3$ \\
\hline
\end{tabular}

* Information.

for I degree of freedom, so there was no evidence of sex-linkage.

Thus, all the evidence pointed to the disease being due to the action of an autosomal recessive gene, except for the 3 normal offspring from matings of affected parents. The first obvious explanation to postulate for these three anomalous animals is incomplete penetrance. In that case the anomalous animals should have been homozygous for the gene concerned and should have been indistinguishable in breeding behaviour from affected animals. Offspring were obtained from two of the animals, when mated to affected sibs. One produced 3 normal, 3 affected, and the other 6 normal, 7 affected, i.e. both bred like heterozygotes rather than homozygotes. However, this evidence is not critical since it was possible that genetic modifiers lowering the penetrance of the gene had accumulated in these particular pairs. One of the two animals left only one further pair of descendants, but the other left several later generations (Table VI), including 3 pairs of affected $x$ affected, which produced 9 affected and no normal young, and a mating of normal $\times$ normal, one of whose normal offspring proved to be homozygous for the wild-type allele. The existence of this normal descendant proves that the anomalous normal ancestor must have carried the wild-type allele of the gene, and the progeny of the affected descendants show that the penetrance of the gene was high. Thus, of the three anomalous animals, one was certainly and another probably heterozygous, and no animal was shown to be a non-manifesting homozygote.

There are various possible ways of explaining how heterozygous offspring could be derived from supposedly homozygous recessive parents.

(I) One of the supposed homozygous parents could in fact have been heterozygous and either wrongly classified as affected or was the result of rare heterozygous expression of the gene. This explanation is possible but unlikely, as the propor-
TABLE VI

SEGREGATION OF FOAM-CELL RETICULOSIS AMONG OFFSPRING OF VARIOUS TYPES OF PAIRS DESCENDED FROM AN ANOMALOUS NORMAL ANIMAL

\begin{tabular}{|c|c|c|c|c|}
\hline \multicolumn{3}{|c|}{ Parents } & \multicolumn{2}{|c|}{ Offspring } \\
\hline Phenotypes & $\begin{array}{l}\text { Postulated } \\
\text { Genotypes }\end{array}$ & $\begin{array}{l}\text { No. of } \\
\text { Pairs }\end{array}$ & Normal & Affected \\
\hline $\begin{array}{l}\text { Both affected } \\
\text { One affected } \\
\text { Both normal }\end{array}$ & $\begin{array}{l}f m f m \times f m f m \\
+f m \times f m f m \\
+f m \times+f m \\
++\times+f m\end{array}$ & $\begin{array}{l}3 \\
4 \\
5 \\
1\end{array}$ & $\begin{array}{l}-12 \\
67 \\
11\end{array}$ & $\begin{array}{r}9 \\
16 \\
18 \\
\end{array}$ \\
\hline
\end{tabular}

tion of affected offspring thrown by these parents was higher than would be expected from heterozygotes.

(2) There could have been clerical error in ascribing the three normal animals to the wrong parents. This again seems unlikely, as the frequency of errors would have to be deplorably high, and such a bad record of mistakes is not found in other stocks in this laboratory. However, this possibility cannot be ruled out.

(3) Back-mutation of the mutant to the normal allele could have occurred. This would imply a remarkably high rate of back-mutation and hence that the mutant allele was unstable. As the possibility of error cannot be ruled out, mutation cannot be proved.

It is not possible to decide which of these three explanations is the correct one, but it is clear that the three anomalous animals do not rule out the hypothesis of a single autosomal recessive gene.

The penetrance of the postulated gene $\mathrm{fm}$ is high in the CBA/H stock, but no crosses to other stocks have been made, nor any linkage tests other than that for sex-linkage.

\section{Discussion}

The pathological and histochemical findings indicate that this foam-cell reticulosis, which has been observed in an inbred strain of mice, can be classified as a lipid-storage disease. The lymphoid tissue of the thymus and Peyer's patches is replaced by cells which store lipoid material in their foamy cytoplasm. Other tissues may also be affected but rarely to the same extent. The disease is not neoplastic.

In spite of the chemical investigations and numerous histochemical tests, it is impossible to be dogmatic about the nature of the stored lipid in this disease. In some ways the chemistry and histochemistry appear to be contradictory. Histochemically the foam-cells contained phospholipid. The chemical investigations did not show an increase in the proportion of phospholipid in diseased tissue, 
but they did reveal the presence of a remarkably high proportion of a component with the properties of lysolecithin which was in a I : I ratio with lecithin. Moreover, the sum of this component and lecithin in the diseased tissue was approximately equal to the amount of lecithin found in normal tissue. It would be expected that lysolecithin, which is a comparatively polar molecule and has only one hydrocarbon chain, would be more easily extracted into aqueous solvents than would other phospholipids. It is not surprising, therefore, that fixation in formol-calcium and post-chromation was necessary when staining sections for fat. The proportion of cholesterol and cholesterol ester was high by chemical examination, but unless the cholesterol was so complex as to prevent successful histochemical tests, it was presumably not sufficiently high to give positive histochemistry. The ratio of cholesterol and cholesterol ester to phospholipid is 3 in the diseased mice as compared with $I$ in the normal mice. These findings make it possible that the diseased mice are storing some complex or complexes containing cholesterol and lysolecithin.

This disease of mice has no exact counterpart amongst the lipid-storage diseases of man, but the similarities are sufficiently close to make comparisons worth while. Chemical estimations revealed three times as much cholesterol in the affected tissues but anatomically the disease is least like the xanthomatoses. The mouse disease was more or less generalized and the serum cholesterol was normal so that only the Hand-Schüller-Christian group need to be considered. However, the mice were free of any lesions in bone which could correspond to the characteristic lesions in the human diseases, and the lesions in the mice were at no stage infiltrated with eosinophils. The foam-cells in the mice were not unlike the histiocytic cells of the older lesions of Hand-Schüller-Christian disease and eosinophilic granuloma of bone, but the multinucleate giant cells, typical of the human diseases, were not present in the mice.

There are closer similarities with Gaucher's disease and Niemann-Pick disease. In Gaucher's disease the lipid is the sphingogalactoside cerasin and in Niemann-Pick disease it is a mixture of sphingomyelin and cholesterol and its esters. The combined storage of cholesterol and a phospholipid in the mouse disease suggests that, chemically, it has a greater affinity with Niemann-Pick disease, but the storage of lysolecithin has no counterpart in man. However, Niemann-Pick disease is nearly always a disease of infants and in this respect the mouse disease is more like Gaucher's disease, which begins later in life. In both human diseases the reticulum cells of the lymphoid tissue are affected in a similar way to those of the mice. The characteristic cell of the mouse disease is more like the Niemann-Pick cell, which has foamy, vacuolated cytoplasm, than the Gaucher cell, which is larger and has a wrinkled fibrillary cytoplasm. In some details the mouse disease is different from both of the human diseases. The splenomegaly, with massive lipid deposition, which gives one of the characteristic clinical signs in the human diseases, was not present in the mouse. Lipid storage in the bone-marrow and the deposits of haemosiderin, both of which are seen in the human diseases, were not present in the affected mice. Lipid storage in nerve cells, which occurs in Niemann-Pick disease and which is an essential pathological feature of Tay-Sachs disease and other forms of amaurotic family idiocy, did not occur in the mouse disease.

Genetically, too, the mouse disease resembles Gaucher's and Niemann-Pick diseases in man. In both of these, and also in Tay-Sachs disease, the majority of cases show an autosomal recessive mode of inheritance, like that found for foam-cell reticulosis in this paper, whereas Hand-SchüllerChristian disease is not inherited (Herndon, 1954). Recent evidence, however, suggests that all three of the inherited human diseases may be genetically heterogeneous. In Gaucher's disease, though most pedigrees show recessive inheritance, there are some in which an autosomal dominant gene seems responsible (Fredrickson and Hofmann, 1960; Hsia, Naylor, and Bigler, 1959). In Niemann-Pick disease, on the other hand, the heterogeneity concerns the time of onset. Typically the disease is one of infancy and is usually detected in the first year of life, but a few cases have been detected in adults, the first well-established instance being that of Pfändler (1953), who described two brothers who died of the disease at ages 29 and 33 . Two surviving brothers of these cases had marked hepatosplenomegaly, and Pfändler considered that this family carried a genetically distinct adult form of the disease. Similarly, amaurotic idiocy, of which Tay-Sachs disease is the infantile form, is known also in juvenile and adult forms, which occur in separate pedigrees and are therefore considered to be genetically distinct (Herndon, 1954; Fredrickson, 1960).

Thus, considering the histological, chemical, and genetic evidence together, the human disease which foam-cell reticulosis of mice most resembles may be an adult form of Niemann-Pick disease.

The stock is available to those interested in making further studies and comparisons of the two diseases. 


\section{Summary}

An inherited lipid-storage disease has occurred in CBA mice. Lipid-containing foam-cells replace the lymphoid tissue of the thymus and Peyer's patches and may occur in smaller numbers in other tissues. Chemical and histochemical investigations suggest that the lipid may be a complex of lysolecithin and cholesterol. The disease appears to be inherited via a single autosomal recessive gene for which the name and symbol foam-cell reticulosis, $f m$, are suggested. It is concluded that this foam-cell reticulosis of mice is very similar to Niemann-Pick disease in man.

The authors are very grateful to Mrs. H. Bowker, Mr. Albert Jackson, and Mr. R. Faulkes for technical assistance.

\section{REFERENCES}

Adams, C. W. M. (196I). A perchloric acid-naphthoquinone method for the histochemical localization of cholesterol. Nature (Lond.), r92, 33I.

Berenblum, I., and Chain, E. (1938). An improved method for the colorimetric determination of phosphate. Biochem. $\mathcal{F}$., 32, 295.
Bloor, W. R. (1916). The determination of cholesterol in blood. f. biol. Chem., 24, 227.

Chargaff, E., Levine, C., and Green, C. (1948). Techniques for the demonstration by chromatography of nitrogenous lipide constituents, sulphur-containing amino acids and reducing sugars. ibid., 175, 67.

Fredrickson, D. S. (1960). Infantile amaurotic family idiocy. In The Metabolic Basis of Inherited Diseases, ed. J. B. Stanbury, J. B. Wyngaarden, and D. S. Fredrickson, p. 553. McGraw-Hill, New York.

- , and Hofmann, A. F. (1960). Gaucher's disease. ibid., p. 603. Green, M. C. (1963). Methods for testing linkage. In Methodology in Mammalian Genetics, ed. W. J. Burdette, pp. 56-82. HoldenDay, San Francisco.

Gurr, E. (1958). Methods of Analytical Histology and Histochemistry. Leonard Hill, London.

Herndon, C. N. (1954). Genetics of the lipidoses. Res. Publ. Ass. nerv. ment. Dis., 33, 239.

Hsia, D. Y., Naylor, J., and Bigler, J. A. (1959). Gaucher's disease: report of two cases in father and son and review of the literature. New Engl. F. Med., 26r, 164 .

Marinetti, G. V., and Stotz, E. (1956). Chromatography of phosphatides on silicic acid impregnated paper. Biochim. biophys. Acta (Amst.), 21, 168.

Pearse, A. G. E. (1960). Histochemistry, Theoretical and Applied, and ed. Churchill, London.

Pfändler, U. (1953). Nouvelles conceptions sur l'hérédité et la pathogénie de la maladie de Niemann-Pick. Helv. med. Acta, 20, 216.

Przetecka, A. (1959). A study of Rawitz's 'inversion staining'. Quart. F. micr. Sci., 100, 231. 